\title{
NOVEL AGENTS FOR ENZYMATIC AND FUNGAL HYDROLYSIS OF STEVIOSIDE
}

\author{
H.M.S. Milagre; L.R. Martins; J.A. Takahashi* \\ Departamento de Química, Universidade Federal de Minas Gerais, Belo Horizonte, MG, Brasil.
}

Submitted: June 13, 2008; Returned to authors for corrections: August 27, 2008; Approved: March 31, 2009.

\begin{abstract}
A comparative study on the potential of some biological agents to perform the hydrolysis of stevioside was carried out, aiming at establishing an alternative methodology to achieve the aglycon steviol or its rearranged derivative isosteviol, in high yields to be used in the preparation of novel bioactive compounds. Hydrolysis reactions were performed by using filamentous fungi (Aspergillus niger, Rhizopus stolonifer and Rhizopus arrhizus), a yeast (Saccharomyces cerevisiae) and enzymes (pancreatin and lipases PL250 and VFL 8000). Pancreatin showed the best hydrolytic activity, furnishing isosteviol at $93.9 \%$ of yield, at $\mathrm{pH} 4.0$, using toluene as a co-solvent. Steviol was produced using both pancreatin at $\mathrm{pH} 7.0$ (20.2\% yield) and A. niger at $\mathrm{pH} 7$ (20.8\% yield).
\end{abstract}

Key words: stevioside, hydrolysis, Aspergillus niger, lipase, pancreatin

\section{INTRODUCTION}

Glycosides consists of a large group of well known compounds possessing an aglycon bounded to one or more sugar units, usually found in large amounts in plants. Natural aglycons have very diversified structures, such as lactones, fatty acids, quinones, antraquinones, terpenoids and steroids. Many glycosides possess biological activities such as antimicrobial, analgesic, anti-hypertensive, among others $(1,7)$. Cardenolides are good examples of bioactive glycosides, possessing high cardiotonic (22) and cytotoxic (5) activities. Other interesting biologically active examples include cucurbitacin glycosides, possessing free-radical scavenging properties (29), antocianins, that promote a protective effect against $\mathrm{H}_{2} \mathrm{O}_{2}$ - or TNF-induced insulin resistance in 3T3-L1 adipocytes (12) and stilbene glycosides, active anti-inflammatory compounds (31).

Studies on structure-activity showed that aglycons can be more active than respective glycosides as related for estrogenic activity (9). In other cases, aglycons may have biological properties not related for the respective glycoside and, therefore, aglycon release from the glycoside moiety becomes a desirable methodology for diversified applications. However, in some cases, glycoside hydrolysis can be a hard accomplishment since the reaction may be not favorable to the need of displacing an unstable OR leaving group (26). Drastic conditions employing strong acids can be used for glycoside hydrolysis but only for compounds containing no labile groups in the aglycon (2).

The use of biological systems, especially fungi and fungal enzymes to carry on chemical reactions, a process named biotransformation (13) attracted attention of chemists and microbiologists since such reactions are accomplished in smooth conditions, not only preserving chemical labile groups in the molecules but also being environment-friendly processes (3).

Stevioside (1), the major constituent of Stevia rebaudiana extract, consists of a glycoside possessing a diterpene named steviol (2) as its aglycon (Fig. 1) (10). Steviol rearrangement to isosteviol (3) (Fig. 2) has been reported from the acid hydrolysis of stevioside (2). Stevioside and steviol are able to decrease glycogen deposition on the organism (11). Steviol also has plant regulatory activity (23), and is able to be used in treatment of diseases associated to insulin resistance (15). Isosteviol acts in the reduction of plasmatic glucose levels (19) and has protective effects against myocardial ischemia-reperfusion injuries (33). Role of isosteviol as a potassium channel opener to lower intracellular calcium concentrations has also been reported (32).

*Corresponding Author. Mailing address: Departamento de Química, ICEx, Universidade Federal de Minas Gerais. Av. Antonio Carlos, 6627, CEP 31270-901, Belo Horizonte, MG, Brazil. Phone +5531-3409-5754; fax +5531-34095700. E-mail: jat@qui.ufmg.br 


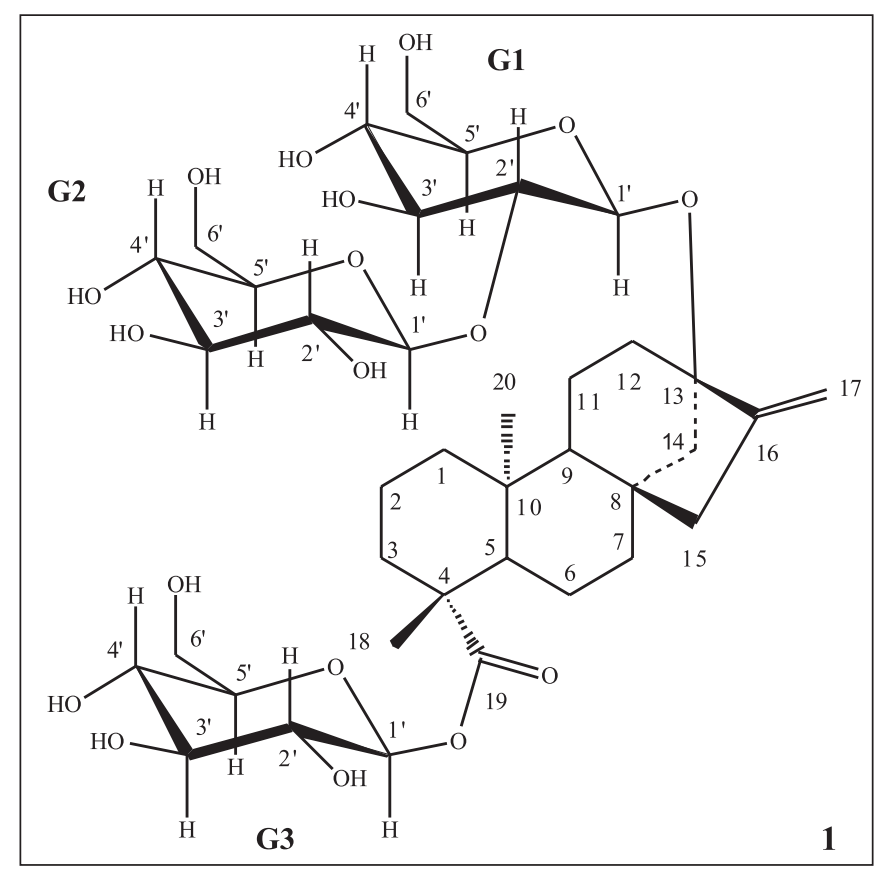

Figure 1. Structure of stevioside (1), showing aglycon in the center surrounded by the glucose groups G1, G2 and G3.

Isosteviol derivatives have been synthesized for evaluation as anti-tuberculosis agents (16).

Many other diterpenes closed related to steviol and isosteviol are reported to be biologically active, for example as a tripanocidal agent (30) or as protective agents to be used against cerebral injuries in ischemia processes (28). Other activities like allelopatic have also been described (20), making steviol-like compounds very interesting targets for bioprospecting of novel biological activities. A difficulty finding on using diterpenes and other natural products in biological screenings is their low availability from natural sources. Steviol and isosteviol consist of a natural cheap source of these.

The objective of this work was to carry out a comparative study on some biological alternative agents that can be used for stevioside (1) hydrolysis in order to obtain steviol (2) and isosteviol (3) in high yields.

\section{MATERIALS AND METHODS}

Stevioside (1) was isolated from Stevita Cristal ${ }^{\circledR}$ (gift of Steviafarma Industrial S.A., Brazil) by silicagel column chromatography followed by recrystallization. Strains of Aspergillus niger CCT4026 and Rhizopus stolonifer CCT2002 were donated by Coleção de Culturas Tropical (São Paulo, Brazil) and the strain of Rhizopus arrhizus NRRL1526 was donated by the Northern Regional Research Laboratories (USA).

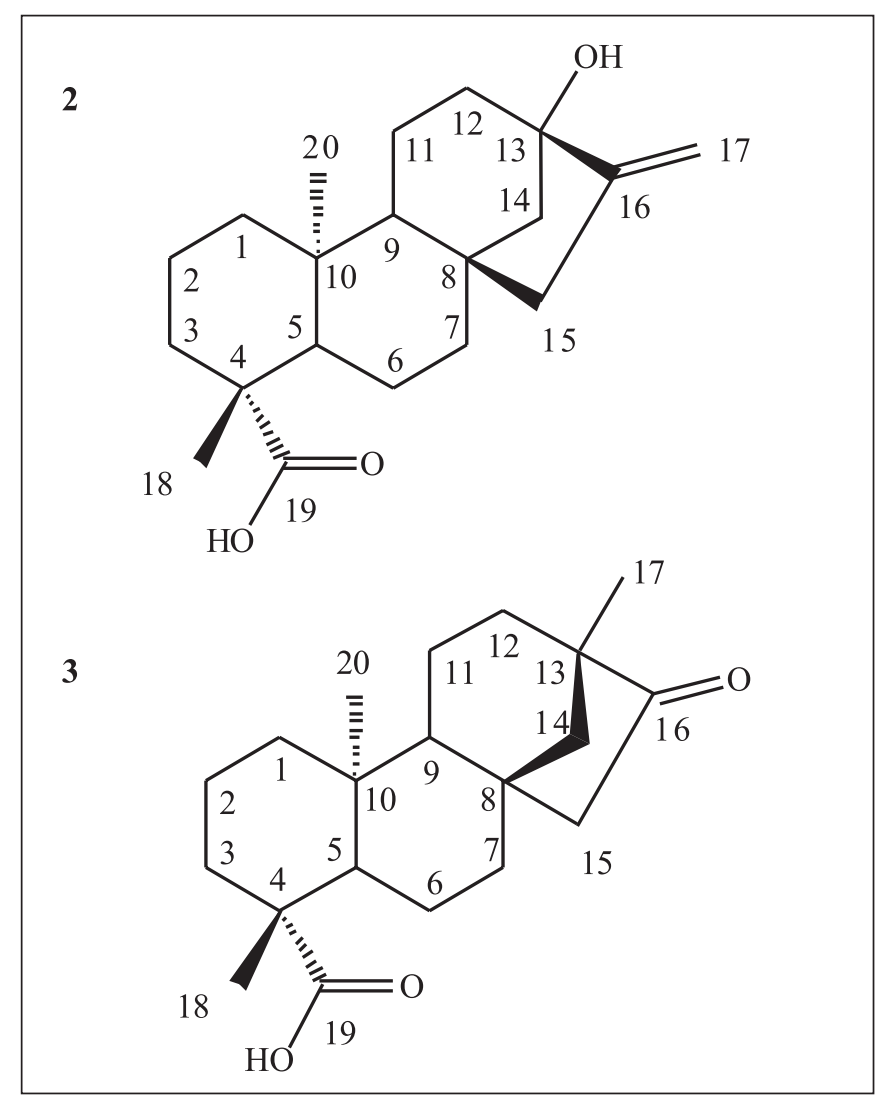

Figure 2. Structure of aglycons steviol (2) and isosteviol (3).

Saccharomyces cerevisiae was isolated from commercial yeast (Fleischmann Royal Nabisco, Brazil). Solvents and reagents were of analytical grade (Merck, Grupo Química, AcuMedia). Enzymes used were Pancreatin (Biobrás, Brazil) and lipases Pancreatic lipase (PL250) and Validase Fungal Lipase, VFL 8000 (Valley Research Inc., South Bend, Indiana, USA)

\section{Reactions conditions}

Hydrolitic properties of the biological systems were evaluated at room temperature $\left(25^{\circ} \mathrm{C}\right)$ for seven days in two $\mathrm{pH}$ systems: 4.0 and 7.0. Toluene or ethanol was added to the reaction system aiming to modify the active sites with consequent yield improvement $(21,25)$.

\section{Enzymatic hydrolysis}

$200.0 \mathrm{mg}$ of stevioside (1) were dissolved in $30.0 \mathrm{~mL}$ of aqueous buffer (citrate or phosphate) and added to $20.0 \mathrm{mg}$ of the enzyme on a round bottom flask. Toluene $(1.0 \mathrm{~mL})$ or ethanol $(10.0 \mathrm{~mL}$ ) was also added (see Table 1). Reaction was followed by TLC each 24 hours. After 7 days, the aqueous mixture was extracted with ethyl acetate and then with butanol. Both ethylacetate and butanol extracts were dried, combined and 
Table 1. Overview of the reactions performed showing yields of products formed and substrate recovery rates under different reaction conditions.

\begin{tabular}{cccccc}
\hline Reagent & $\mathrm{pH}$ & $\begin{array}{c}\text { Solvent/reagent } \\
\text { added }\end{array}$ & $\begin{array}{c}\text { Hydrolysis } \\
\text { product }\end{array}$ & $\begin{array}{c}\text { Hydrolysis } \\
\text { yield }(\%)\end{array}$ & $\begin{array}{c}\text { Substrate recovery } \\
\text { rate }(\%)\end{array}$ \\
\hline Pancreatin & 4.0 & toluene & isosteviol & 93.9 & 0 \\
Pancreatin & 4.0 & ethanol & isosteviol & 12.4 & 76.0 \\
Pancreatin & 7.0 & toluene & steviol & 20.2 & 51.5 \\
Pancreatin & 7.0 & ethanol & 0 & 0 & 97.6 \\
Pancreatic lipase & 4.0 & toluene & 0 & 0 & 98.4 \\
Pancreatic lipase & 4.0 & ethanol & steviol & 5.2 & 82.2 \\
Pancreatic lipase & 7.0 & toluene & 0 & 0 & 97.3 \\
Pancreatic lipase & 7.0 & ethanol & isosteviol & 4.2 & 80.4 \\
Fungal lipase & 4.0 & toluene & 0 & 0 & 86.7 \\
Fungal lipase & 4.0 & ethanol & steviol & 10.0 & 97.1 \\
Fungal lipase & 7.0 & toluene & 0 & 0 & 97.0 \\
Fungal lipase & 7.0 & ethanol & 0 & 0 & 38.1 \\
A. niger & 7.0 & none & steviol & 20.8 & 75.9 \\
R. arrhizus & 7.0 & none & 0 & 0 & 63.2 \\
R. stolonifer & 7.0 & none & 0 & 0 & 26.2 \\
S. cerevisiae & 7.0 & glucose & 0 & 0 & 0 \\
S. cerevisiae & 7.0 & none & 0 & 0 & \\
\hline
\end{tabular}

analyzed by TLC using steviol (2) and isosteviol (3) as standards.

\section{Fungal hydrolysis}

Bioreactions using fungi were carried out in Sabouraud Dextrose Broth (SDB). Five conical flasks containing $200 \mathrm{~mL}$ of sterile SDB medium were used for each reaction. After sterilization and cooling, the flasks were inoculated with a fresh sample of the specific fungal strain and let to reach the exponential phase under an orbital stirring. Then, $2 \mathrm{~mL}$ of stevioside (1) in an aqueous solution $(25 \mathrm{mg} / \mathrm{mL})$ were added to each flask. Control experiments containing only the fungus (cells control) and only stevioside (substrate control) were run in parallel. After 7 days, the mycelia were filtered off and the aqueous broth was extracted from ethylacetate, dried and analyzed by TLC using steviol (2) and isosteviol (3) as standards.

\section{Yeast hydrolysis}

$20.0 \mathrm{~g}$ of dehydrated Saccharomyces cerevisiae in $10.0 \mathrm{~mL}$ of distilled water were added to a solution containing $0.0128 \mathrm{~g}$ of $\mathrm{ZnSO}_{4}$ and $10 \mathrm{~g}$ of glucose in $10 \mathrm{~mL}$ of distilled water. The system was left over magnetic stirring for $30 \mathrm{~min}$ at $30^{\circ} \mathrm{C}$ for yeast activation. Then, $1.0 \mathrm{mmol}(0.5002 \mathrm{~g})$ of stevioside (1) was added. The procedure was repeated without glucose addition. After 7 days, the media were extracted with ethylacetate, dried and analyzed by TLC using steviol (2) and isosteviol (3) as standards.

\section{Determination of products yields}

In all cases, yields and remaining substrate present in the reaction were determined after column chromatography and isolation of products. ${ }^{13} \mathrm{C}$ NMR data, used for determining products structures, in comparison with data obtained for starting material, stevioside (1), are found on Table 2. Table 3 shows data for carbons present in the glucose moieties belonging to the stevioside skeleton, as determined by ${ }^{13} \mathrm{C}$ NMR spectroscopy.

\section{RESULTS AND DISCUSSION}

HPLC analysis of the crude extract showed stevioside (1) to be present in $59.38 \%$ of the extract. This substance was isolated as a single compound by silica gel column chromatography (ethylacetate/methanol 9:1) and then characterized by ${ }^{1} \mathrm{H}$ and ${ }^{13} \mathrm{C}$ NMR spectra as being the $13-\mathrm{O}-[\beta-$ D-glucopyranosil- $(1 \rightarrow 2)$ - $\alpha$-D-glucopyranoside] $\beta$-Dglycopyranoside ester of steviol. ${ }^{13} \mathrm{C}$ NMR spectrum was able to show the chemical shifts for all three sugar units present in stevioside (1) skeleton, an addition to the literature data that presented the chemical shifts for only two glucose units (35). NMR data are presented in Tables 2 and 3.

Four biological systems were used to carry out the enzymatic hydrolysis of stevioside: pancreatin (an enzymatic complex), lipases of two different sources (Pancreatic PL250 Lipase and Fungal VFL 8000 Lipase), filamentous fungi (Aspergillus niger, 
Table 2. ${ }^{13} \mathrm{C}$ NMR chemical shifts $(\delta, 50 \mathrm{MHz})$ for stevioside aglycon $\left(\mathbf{1}, \mathrm{D}_{2} \mathrm{O}\right)$, steviol $\left(\mathbf{2}, \mathrm{CDCl}_{3}\right)$ and isosteviol $\left(\mathbf{3}, \mathrm{CDCl}_{3}\right)$.

\begin{tabular}{cccc}
\hline C & Stevioside $(\mathbf{1})$ & Steviol (2) & Isoesteviol $(\mathbf{3})$ \\
\hline 1 & 40.7 & 40.6 & 40.0 \\
2 & 19.0 & 19.0 & 19.2 \\
3 & 38.1 & 37.8 & 37.3 \\
4 & 44.1 & 43.6 & 43.6 \\
5 & 57.2 & 56.9 & 57.0 \\
6 & 21.8 & 21.8 & 21.9 \\
7 & 41.5 & 41.3 & 41.6 \\
8 & 42.5 & 41.7 & 48.7 \\
9 & 53.6 & 53.8 & 54.7 \\
10 & 39.6 & 39.5 & 38.2 \\
11 & 20.4 & 20.5 & 20.3 \\
12 & 36.1 & 39.3 & 38.2 \\
13 & 85.8 & 80.4 & 39.5 \\
14 & 44.1 & 47.4 & 54.3 \\
15 & 47.2 & 47.0 & 48.6 \\
16 & 153.8 & 155.9 & 222.6 \\
17 & 104.2 & 103.0 & 19.9 \\
18 & 28.1 & 28.8 & 29.3 \\
19 & 176.8 & 182.3 & 180.5 \\
20 & 15.1 & 15.5 & 13.5 \\
\hline
\end{tabular}

Table 3. ${ }^{13} \mathrm{C}$ NMR chemical shifts $\left(\delta, \mathrm{D}_{2} \mathrm{O}, 50 \mathrm{MHz}\right)$ for carbons of glucose groups G1, G2 and G3, present in stevioside skeleton.

\begin{tabular}{cccc}
\hline C & G1 & G2 & G3 \\
\hline 1' & 97.1 & 106.1 & 94.9 \\
2' & 84.1 & 75.9 & 73.2 \\
3' & 77.7 & 76.9 & 78.0 \\
4' & 71.3 & 71.9 & 70.4 \\
5' & 77.9 & 77.0 & 78.3 \\
6' & 62.6 & 62.8 & 61.8 \\
\hline
\end{tabular}

Rhizopus arrhizus and Rhizopus stolonifer) and the yeast Saccharomyces cerevisiae.

Reactions with enzymes were carried out at two pHs, 4.0 and 7.0, since literature relates these both as the optimum $\mathrm{pHs}$ for ester hydrolysis in acidic and basic pHs, respectively (4). The reactions were left for 7 days and experiments were carried out in duplicate: to a set of experiments toluene was added (25) and, to the second set, ethanol was added (21). Organic solvents were added to the reactions aiming at promoting solvatation of reaction intermediaries and to cause beneficial modifications in enzymes conformations. When lipases are concerned, addition of an organic solvent to the aqueous environment causes conformational alterations that can result on an increase of the hydrophobic sites (17).

Table 1 shows the results found for the hydrolysis of stevioside (1) under the different tested conditions. Pancreatin presented different behavior according to the $\mathrm{pH}$ parameter. At $\mathrm{pH} 4$, isosteviol (3) was the isolated product, whereas at $\mathrm{pH} 7.0$, steviol (2) was formed. At $\mathrm{pH} 4.0$, the presence of toluene increased almost 8 times the product's yield, with no recovery of starting material, while, using ethanol, $76 \%$ of unmodified stevioside (1) was recovered, showing that addition of this solvent did not lead to a yield increasing. Indeed, at $\mathrm{pH}$ 7.0, addition of ethanol led to a nearly complete recovery of starting material. No other tested condition showed to be as good as the use of pancreatin to obtain isosteviol (3) that was also produced by the action of pancreatic lipase (Table 1) upon addition of ethanol, at $\mathrm{pH}$ 7.0, but on a much lower yield (4.2\%). At the same condition but $\mathrm{pH} 4.0$, steviol (2) was formed, also on a low yield (5.2\%).

Steviol was obtained from the experiments on three tested conditions: with pancreatin/ethanol at $\mathrm{pH} 7.0$ (20.2\%), using fungal lipase/ethanol at $\mathrm{pH} 4.0(10 \%)$ and also by using A. niger, at $\mathrm{pH} 7.0(20.8 \%)$. The other two fungal species used in this experiment were unable to carry on the desirable reaction. It is interesting to observe that $S$. cerevisiae did not produce steviol (2) neither isosteviol (3), but consumed all stevioside (1) from the medium when glucose was not added.

Enzymatic hydrolysis of stevioside (1) into steviol (2) was previously accomplished by using hesperidinase, an enzymatic complex able to break glycoside bonds (14) and also by using the fungus Aspergillus niger, a filamentous fungus known to synthesize hydrolytic enzymes such as $\alpha$-L-ramnosidase and $\beta$-D-glucosidase (21). Other successful examples of glycoside hydrolysis by means of biological reagents are the hydrolysis of isoflavone glycosides by bacteria (6), with yields ranging from 25 to $80 \%$.

Although the low yields of experiments for obtaining steviol (2), in some cases, recovery of stevioside (1) was high, implying that reaction yields can be improved, either by increasing the reaction time (27), altering chemical composition of the medium $(24,35)$, changing a substrate feeding procedure (8) or by the use of reactors with controlled reaction conditions (18). On other hand, even methodologies leading to low yields of aglycons without side reactions are of huge interest since acidic conditions can not guarantee aglycon stability in some specific cases. Microbial reactions tend to increase since the mild reaction conditions are in good agreement with the present tendency to a green chemistry.

\section{ACKNOWLEDGEMENTS}

To Dr. Sergio D. Segall for the gift of some enzymes. To Steviafarma Industrial S.A., for providing Stevita crystal ${ }^{\circledR}$ 
samples and to Coleção de Culturas Tropical (CCT, Brazil) and the Northern Regional Research Laboratories (NRRL, USA) for the gifts of fungal cultures. To FAPEMIG for financial support and $\mathrm{CNPq}$ for grants.

\section{RESUMO}

\section{Novos agentes para a hidrólise enzimática e fúngica do esteviosídeo}

Um estudo comparativo do potencial de alguns agentes biológicos capazes de hidrolisar o esteviosídeo foi realizado, objetivando-se estabelecer uma metodologia alternativa para a obtenção da aglicona esteviol ou seu produto de rearranjo, isoesteviol, em rendimentos elevados que permitam o uso destas agliconas para o preparo de novos compostos bioativos. As reações de hidrólise foram realizadas usando fungos filamentosos (Aspergillus niger, Rhizopus stolonifer e Rhizopus arrhizus), uma levedura (Saccharomyces cerevisiae) e enzimas (pancreatina, lipase PL250 e lipase VFL 8000). A pancreatina mostrou a melhor atividade hidrolítica dentre os sistemas testados, fornecendo isoesteviol com rendimento de $93,9 \% \mathrm{em}$ $\mathrm{pH} 4,0$, usando tolueno como co-solvente. Esteviol foi produzido tanto usando pancreatina em $\mathrm{pH} 7,0(20,2 \%$ de rendimento) quanto usando $A$. niger em $\mathrm{pH} 7,0(20,8 \%$ de rendimento).

Palavras-chave: esteviosídeo, hidrólise, Aspergillus niger, lipase, pancreatina

\section{REFERENCES}

1. Ali, Z.; Khan, S.I.; Khan, I.A. (2006). Phytochemical study of Actaea rubra and biological screenings of isolates. Planta Medica 72 (14), 1350-1352.

2. Avent, A.G.; Hansons, J.R.; Oliveira, B.H. (1990). Hydrolysis of the diterpenoid glycoside, stevioside. Phytochemistry 29 (8), 2712-2715.

3. Boaventura, M.A.D.; Lopes, R.F.A.; Takahashi, J.A. (2004). Microorganisms as tools in modern chemistry: The biotransformation of 3-indolycetonitrile and tryptamine by fungi. Braz. J. Microbiol. 35 (4), 345-347.

4. Boyer, C.D. (1985). Soluble starch synthases and starch branching enzymes from developing seeds of sorghum. Phytochemistry 24 (1), 15-18.

5. Cheenpracha, S.; Karalai, C.; Rat-a-Pa, Y.; Ponglimanont, C.; Chantrapromma, K. (2004). New Cytotoxic cardenolide glycoside from the seeds of Cerbera manghas. Chem. Pharm. Bull. 52 (8), 1023-1025.

6. Choi, Y.; Kim, K.; Rhee, J. (2002). Hydrolysis of soybean isoflavone glucosides by lactic bactgeria. Biotechnol. Lett. 24 (24), 2113-2116.

7. Dembitsky, V.M. (2004). Chemistry and biodiversity of the biologically, Active Natural Glycosides. Chem. Biodiv. 01, 673-781.

8. Dhake, A.B.; Patil, M.B. (2007). Effect of substrate feeding on production of fructosyltransferase by Penicillium purpurogenum. Braz. J. Microbiol. 38 (2), 194-199.

9. Garritano, S.; Pinto, B.; Giachi, I.; Pistelli, L.; Reali, D. (2005). Assessment of estrogenic activity of flavonoids from mediterranean plants using an in vitro short-term test. Phytomedicine 12 (1-2), 143-147.

10. Geuns, J.M.C. (2003). Stevioside. Phytochemistry 64 (5), 913-921.

11. Ghisalberti, E.L. (1997). The biological activity of naturally occurring kaurane diterpenes. Fitoterapia 68, 303-326.

12. Guo, H.; Ling. W.; Wang, Q.; Liu, C.; Hu, Y.; Xia, M. (2008). Cyanidin 3-glycoside protects 3T3-L1 adipocytes against $\mathrm{H}_{2} \mathrm{O}_{2}$ - or TNF- alpha-induced insulin resistance by inhibiting c-Jun $\mathrm{NH}_{2-}$ terminal kinase activation. Biochem. Pharmacol. 75 (6), 1393 1401 .

13. Hanson, J.R. (1995). An Introduction to biotransformations in organic chemistry. Ed. W.H. Freeman, Chichester, UK.

14. Hanson, J.R.; Oliveira, B.H. (1990). The microbiological transformation of steviol derivates by Rhizopus stolonifer and Gibberella fugikuroi. Phytochemistry 29 (12), 3805-3807.

15. Hermansen, K.; Bendix Jeppesen, P. (2008). Treatment of insulin resistance and diseases associated with insulin resistance. PCT Inst. Appl. (WO 2008/031439). 75 pp.

16. Kataev, V.E.; Militsina, O.I.; Strobykina, I.Y.; Kovylyaeva, G.I.; Musin, R.Z.; Fedorova, O.V.; Rusinov, G.L.; Zueva, M.N.; Mordovskoi, G.G.; Tolstikov, A.G. (2006). Synthesis and antituberculous activity of diesters based on isosteviol and dicarboxylic acids. Arbuzov Pharm. Chem. J. 40 (9), 473-475.

17. Koops, B.C.; Verheij, H.M.; Slotboom, A.J.; Egmond, M.R. (1999). Effects of chemical modification on the activity of lipases in organic solvents. Enz. Microbiol. Techol. 25, 622-631.

18. Linde, G.A.; Magagnin, G.; Costa, J.A.V. (2007). Column bioreactor use for optimization of pectinase production in solid substrate cultivation. Braz. J. Microbiol. 38 (3), 557-562.

19. Ma, J.; Ma, Z.; Wang, J.; Milne, R.W.; Xu, D.; Davey, A.K.; Evans, A.M. (2007). Isosteviol reduces plasma glucose levels in the intravenous glucose tolerance test in Zucker diabetic fatty rats. Diabetes, Obesity and Metabolism 9 (4), 597-599.

20. Macias, F.A.; Lopez, A.; Varela, R.M.; Torres, A.; Molinilo, J.M.G (2008). Helikauranoside A, a new bioactive diterpene. J. Chem. Ecol. 34 (1), 65-69.

21. Mizukani, H.; Shiba, K.; Ohashi, H. (1982). Enzymatic determination of stevioside in Stevia rebaudiana. Phytochemistry 21 (8), 19271930.

22. Morales, C.; Cusido, R.; Palazon, J.; Bonfill, M.; Pinol, M.T. (1997). Digitalis plants and tissue cultures, improved conditions for cardenolide production. Curr. Top. Plant Biol. 1, 1-15.

23. Oliveira, B.H.; Stirmer, J.C.; de Souza Filho, J.D.; Ayub, R.A. (2008). Plant growth regulation activity of steviol and derivates. Phytochemistry 69 (7), 1528-1533.

24. Pio, T.F.; Fraga, L.P.; Macedo, G.A. (2008). Inoculum padronization for the production of cutinase by Fusarium oxysporum. Braz. J. Microbiol. 39 (1), 74-77.

25. Ruddat, M.; Heftmann, E.; Lang, A. (1965). Biosynthesis of steviol. Arch. Biochem. Biophys. 110, 496-499.

26. Smith, M.B.; March, J. (2007). March's advanced organic chemistry - reactions, mechanisms and structure $-6^{\text {th }}$ edition. WileyInterscience. John Willey \& Sons, Inc. Hoboken, New Jersey, USA.

27. Takahashi, J.A.; Barroso, H.A.; Oliveira, A.B. (2000). Optimization of diterpenes bioconversion process by fungus Chephalosporium aphidicola. Braz. J. Microbiol. 31 (2), 83-86.

28. Tan, W. (2005). The use of kauranes compounds in the manufacture of medicament. PCT Int. Appl. (WO 2005/110383). 35 pp.

29. Tannin-Spitz, T.; Bergman, M.; Grossman, S. (2007). Cucurbitacin glycosides: Antioxidant and free-radical scavenging activities. Biochem. Biophys. Res. Comm. 364 (1), 181-186.

30. Vieira, H.S.; Takahashi, J.A.; Silva, E.A.; Boaventura, M.A.D.; Oliveira, A.; Chiari, E. (2002). Preparation and activity of diterpenoids against trypomastigotes of Trypanosoma cruzi. Rev. Bras. Farmacognosia 12, 118-120. 
31. Wang, X.; Zhao, L.; Han, T.; Chen, S.; Wang, J. (2008). Protective effects of 2,3,5,4'-tetrahydroxystilbene-2-O-beta-D-glucose, an active component of Polygonum multiflorum Thunb, on experimental colitis in mice. Eur. J. Pharmacol. 578 (2), 339348.

32. Wong, K.; Yang, H.; Chan, P.; Cheng, T.; Liu, J.; Hsu, F.; Liu, I.; Cheng, Y.; Cheng, J. (2004). Isosteviol as a potassium channel opener to lower intracellular calcium concentrations in cultured aortic smooth muscle cells. Planta Medica 70 (2), 108-112.
33. Xu, D.; Zhang, S.; Foster, D.J.R.; Wang, J. (2007). The effects of isosteviol against myocardium injury induced by ischaemiareperfusion in the isolated guinea pig heart. Clin. Exp. Pharmacol. Phys. 34 (5/6), 488-493.

34. Yamanaka, R.; Soares, C.F.; Matheus, D.R. (2008). Lignolytic enzymes produced by Trametes villosa ccb176 under different culture conditions. Braz. J. Microbiol. 39 (1), 78-84.

35. Yamasaki, K.; Kohda, H.; Kobayashi, T.; Kasai, R.; Tanaka, O. (1976). Structures of the Stevia diterpene-glucosides: application of ${ }^{13} \mathrm{C}$ NMR. Tet. Lett. 13, 1005-1008. 